\title{
Correction: Consensus disease definitions for neurologic immune-related adverse events of immune checkpoint inhibitors
}

Guidon AC, Burton LB, Chwalisz BK, et al. Consensus disease definitions for neurologic immune-related adverse events of immune checkpoint inhibitors. JImmunoTher Cancer 2021;9:e002890. doi: 10.1136/jitc-2021-002890

This article has been corrected since it was first published. A section of Table 6 was missing in the guideline criteria column and has now been added.

Open access This is an open access article distributed in accordance with the Creative Commons Attribution Non Commercial (CC BY-NC 4.0) license, which permits others to distribute, remix, adapt, build upon this work non-commercially, and license their derivative works on different terms, provided the original work is properly cited, appropriate credit is given, any changes made indicated, and the use is non-commercial. See http://creativecommons.org/licenses/by-nc/4.0/.

(C) Author(s) (or their employer(s)) 2021. Re-use permitted under CC BY-NC. No commercial re-use. See rights and permissions. Published by BMJ.

J Immunother Cancer 2021;9:e002890corr1. doi:10.1136/jitc-2021-002890corr1

D) Check for updates 